Article

\title{
A Highly-Sensitive Picric Acid Chemical Sensor Based on ZnO Nanopeanuts
}

\author{
Ahmed A. Ibrahim 1,2,3 , Preeti Tiwari ${ }^{4}$, M. S. Al-Assiri ${ }^{2,5}$, A. E. Al-Salami ${ }^{6}$, Ahmad Umar ${ }^{1,2, *}$, \\ Rajesh Kumar ${ }^{7}$, S. H. Kim ${ }^{1,2}$, Z. A. Ansari ${ }^{4}$ and S. Baskoutas ${ }^{3}$ \\ 1 Department of Chemistry, Faculty of Science and Arts, Najran University, P.O. Box 1988, Najran 11001, \\ Saudi Arabia; ahmedragal@yahoo.com (A.A.I.); semikim77@gmail.com (S.H.K.) \\ 2 Promising Centre for Sensors and Electronic Devices (PCSED), Najran University, P.O.Box-1988, \\ Najran 11001, Saudi Arabia; msassiri@gmail.com \\ 3 Department of Materials Science, University of Patras, Patras GR-26504, Greece; bask@upatras.gr \\ 4 Centre for Interdisciplinary Research in Basic Sciences, Jamia Millia Islamia, New Delhi 110025, India; \\ preet.19.pt@gmail.com (P.T.); zaansari@jmi.ac.in (Z.A.A.) \\ 5 Department of Physics, Faculty of Science and Arts, Najran University, P.O. Box 1988, Najran 11001, \\ Saudi Arabia \\ 6 Department of Physics, Faculty of Science, King Khalid University, P.O. Box-9004, Abha 61413, Saudi Arabia; \\ Salami11@gmail.com \\ 7 PG Department of Chemistry, JCDAV College, Dasuya, Punjab 144205, India; rk.ash2k7@gmail.com \\ * Corresponding: ahmadumar.asp@gmail.com or ahmadumar786@gmail.com; Tel.: +966-5-3457-4597
}

Received: 2 June 2017; Accepted: 8 July 2017; Published: 13 July 2017

\begin{abstract}
Herein, we report a facile synthesis, characterization, and electrochemical sensing application of $\mathrm{ZnO}$ nanopeanuts synthesized by a simple aqueous solution process and characterized by various techniques in order to confirm the compositional, morphological, structural, crystalline phase, and optical properties of the synthesized material. The detailed characterizations revealed that the synthesized material possesses a peanut-shaped morphology, dense growth, and a wurtzite hexagonal phase along with good crystal and optical properties. Further, to ascertain the useful properties of the synthesized $\mathrm{ZnO}$ nanopeanut as an excellent electron mediator, electrochemical sensors were fabricated based on the form of a screen printed electrode (SPE). Electrochemical and current-voltage characteristics were studied for the determination of picric acid sensing characteristics. The electrochemical sensor fabricated based on the SPE technique exhibited a reproducible and reliable sensitivity of $\sim 1.2 \mu \mathrm{A} / \mathrm{mM}\left(9.23 \mu \mathrm{A} \cdot \mathrm{mM}^{-1} \cdot \mathrm{cm}^{-2}\right)$, a lower limit of detection at $7.8 \mu \mathrm{M}$, a regression coefficient $\left(R^{2}\right)$ of 0.94 , and good linearity over the $0.0078 \mathrm{mM}$ to $10.0 \mathrm{mM}$ concentration range. In addition, the sensor response was also tested using simple $I-V$ techniques, wherein a sensitivity of $493.64 \mu \mathrm{A} \cdot \mathrm{mM}^{-1} \cdot \mathrm{cm}^{-2}$, an experimental Limit of detection (LOD) of $0.125 \mathrm{mM}$, and a linear dynamic range (LDR) of $1.0 \mathrm{mM}-5.0 \mathrm{mM}$ were observed for the fabricated picric acid sensor.
\end{abstract}

Keywords: $\mathrm{ZnO}$ nanopeanuts; hydrothermal; electrochemical sensor; picric acid

\section{Introduction}

Electrochemical nanotechnology is an emerging combinational technique that involves electrochemical methods, and nanotechnology has been explored for many important applications in fields such as gas sensors, biosensors, electrochemical sensors, electronics, photovoltaic devices, supercapacitors, $\mathrm{pH}$ sensors, and humidity sensors [1,2]. Among the various applications, electrochemical detection and the sensing of hazardous and toxic chemicals are of utmost importance. Semiconductor metal oxide nanomaterials act as efficient electron mediators for the modification and fabrication of highly sensitive electrodes [3,4]. Among the various metal oxide nanomaterials, the 
ZnO-II-VI semiconductor, with a low band gap energy of $3.37 \mathrm{eV}$ and a large exciton binding energy of $60 \mathrm{MeV}$, is extensively studied [5]. Due to its tetrahedral structure and polar symmetry along the hexagonal axis of the wurtzite phase, $\mathrm{ZnO}$ with a variety of morphologies having high surface defect density can be synthesized [6-14]. These morphologies provide a large surface area for the adsorption of chemical species, which is a key factor for efficient electrochemical sensor applications $[11,15]$. As $\mathrm{ZnO}$ nanomaterials are $n$-type semiconductors, the adsorbed chemical species are reduced. Such redox changes on the surface of $\mathrm{ZnO}$ nanomaterials make these materials efficient electron mediators in the electrochemical sensor fabrication process $[10,13]$.

$\mathrm{ZnO}$ nanostructures of different morphologies have been recently reported in the literature for their electrochemical applications for the detection of harmful, toxic, and even biologically important chemical substances [16-18]. Molaakbari et al. [19] fabricated a carbon paste electrode modified with $\mathrm{ZnO}$ nanorods and 5-(4'-amino-3'-hydroxy-biphenyl-4-yl)-acrylic acid (3,4'-AAZCPE) electrochemical sensors for levodopa, a precursor of the neurotransmitter dopamine, which is widely used in the clinical treatment of Parkinson's disease. The selective and sensitive determination of calcitonin was also reported by Patra et al. [20] in human blood serum samples using an electrochemical sensor comprising a medullary thyroid carcinoma marker imprinted polymer onto the surface of $\mathrm{ZnO}$ nanostructures. High sensitivity, a low detection limit, and a response time of $\sim 26.58$ $\mu \mathrm{A} \cdot \mathrm{cm}^{-2} \cdot \mathrm{mM}^{-1}, \sim 5 \mathrm{nM}$ and $10 \mathrm{~s}$, respectively were observed during the electrochemical sensing of ammonia at room temperature using $\mathrm{ZnO}$ nano pencil based electrochemical sensors [21,22]. Mehta et al. [23] reported an ultra-high sensitivity of $\sim 97.133 \mu \mathrm{A} \cdot \mathrm{cm}^{-2} \cdot \mu \mathrm{M}^{-1}$ and a very low detection limit of $147.54 \mathrm{nM}$ for hydrazine using a well-crystallized $\mathrm{ZnO}$ nanoparticle based amperometric sensor. A pristine $\mathrm{ZnO}$ nanorods array deposited on an inert alloy substrate were used as an efficient electron mediator for the fabrication of a hydrazine electrochemical sensor with a sensitivity of $\sim 4.48 \mu \mathrm{A} \cdot \mu \mathrm{M}^{-1} \cdot \mathrm{cm}^{-2}$ [24]. One-dimensional (1D) $\mathrm{ZnO}$ nanorods and two-dimensional (2D) $\mathrm{ZnO}$ nanoflakes synthesized on an Au-coated substrate through a sonochemical approach showed 11.86 and $7.74 \mu \mathrm{A} \cdot \mathrm{M}^{-1}$ sensitivities, respectively, for cortisol, a steroid hormone [25]. Additionally, other chemicals such as glucose [26-29], urea [30,31], uric acid [32], ethanol [33-36], nitrophenols [37], trinitrotoluene [38], nitrophenyl amine [39,40], and ethanolamine [41] are also detected through $\mathrm{ZnO}$ nanostructure-mediated electrochemical sensors.

Phenols and their derivatives, particularly 2,4,6-Trinitrophenol (Picric acid), find extensive application in many industries, such as pharmaceuticals, polymers, leathers, agriculture, fuel cells, and explosives $[10,14]$. Picric acid is a highly toxic and carcinogenic chemical and drastically affects the liver, kidney, eyes, and the respiratory tract [42,43]. A fast, reliable, and selective detection and sensing of even a low level of picric acid is thus required.

In this report, we present a facile, low-temperature solution method for $\mathrm{ZnO}$ nanoparticles with peanut shapes. Further, a highly sensitive picric acid electrochemical sensor based on $\mathrm{ZnO}$ nanopeanuts was fabricated for the sensing of picric acid.

\section{Experimental Details}

\subsection{Materials}

For the synthesis of the $\mathrm{ZnO}$ nanopeanuts and the fabrication of the picric acid electrochemical sensor, Zinc nitrate hexahydrate $\left(\mathrm{Zn}\left(\mathrm{NO}_{3}\right)_{2} \cdot 6 \mathrm{H}_{2} \mathrm{O}\right)$, polyethylene glycol, butyl carbitol acetate (BCA), and ammonium hydroxide $\left(\mathrm{NH}_{4} \mathrm{OH}\right)$ were purchased from Loba Chemie (Mumbai, India), and were used as received without any further purification. Triple deionized (DI) water was used as a solvent for the preparation of solutions.

\subsection{Synthesis of $\mathrm{ZnO}$ Nanopeanuts}

In a typical reaction process for the synthesis of $\mathrm{ZnO}$ nanopeanuts, $0.1 \mathrm{M}$ Zinc nitrate hexahydrate $\left(\mathrm{Zn}\left(\mathrm{NO}_{3}\right)_{2} \cdot 6 \mathrm{H}_{2} \mathrm{O}\right)$, was dissolved in $50 \mathrm{~mL}$ of DI water and mixed well, stirring with $0.2 \mathrm{~g}$ polyethylene 
glycol prepared in $50 \mathrm{~mL}$ of DI water. The stirring was continued for $30 \mathrm{~min}$. After stirring, a few drops of ammonium hydroxide $\left(\mathrm{NH}_{4} \mathrm{OH}\right)$ were mixed in the resultant solution to maintain the solution at a $\mathrm{pH}=10.15$. The resultant solution was again stirred for $20 \mathrm{~min}$, and then transferred to a Teflon-lined autoclave for hydrothermal reaction at $170{ }^{\circ} \mathrm{C}$ for $7 \mathrm{~h}$. On completion, the autoclave was cooled to room temperature, the white precipitates were decanted and washed with DI water to neutralize the $\mathrm{pH}$, and finally dried at $80^{\circ} \mathrm{C}$ in a convection oven.

\subsection{Characterizations of $\mathrm{ZnO}$ Nanopeanuts}

Detailed analytical and characterization techniques were used for the evaluation of the morphological, structural, crystalline, and optical properties of the hydrothermally synthesized $\mathrm{ZnO}$ nanopeanuts. Field emission scanning electron microscopy (FESEM; JEOL-JSM-7600F, JEOL Ltd., Tokyo, Japan) attached with Energy Dispersive Spectroscopy (EDS) was used to study the morphological, structural, and compositional features of the $\mathrm{ZnO}$ nanomaterials. Phase crystallinity and microstructural parameters were evaluated through X-ray diffraction (XRD, PAN analytical Xpert Pro.) in the scan range of $10^{\circ}-80^{\circ}(2 \theta)$ angles using a $\mathrm{Cu}-\mathrm{K} \alpha$ radiation source with a wavelength of $1.54 \AA$. The compositional, optical, and Raman scattering spectral properties of the $\mathrm{ZnO}$ nanopeanuts were analyzed through Fourier transform infrared spectroscopy (FTIR; Perkin Elmer-FTIR Spectrum-100, Perkin Elmer, Germany) in the scan range of 450-4000 $\mathrm{cm}^{-1}$, a UV-visible spectrophotometer (Perkin Elmer-UV/VIS-Lambda 950, Perkin Elmer, Germany) in the absorption range of 200-800 nm, and Raman scattering spectroscopy (Perkin Elmer-Raman Station 400 series, Perkin Elmer, Germany) in the scan range of $200-700 \mathrm{~cm}^{-1}$, respectively.

\subsection{Fabrication of Electrochemical Sensor Based on Screen Printed Electrode (SPE)}

Two sensor techniques i.e., electrochemical and simple current-voltage (I-V) techniques, were chosen to characterize the fabricated picric acid sensor using synthesized $\mathrm{ZnO}$ nanopeanuts. The in-house SPE was fabricated using Printed circuit board (PCB) technology on a glass epoxy substrate, which consisted of a three electrode system viz. working, counter, and reference electrode. All of the three electrodes were gold plated (Scheme 1). The working electrode (surface area $0.13 \mathrm{~cm}^{2}$ ) was used for the coating of synthesized $\mathrm{ZnO}$ nanopeanuts by formulating a thick paste as reported elsewhere [44]. The paste was prepared by mixing a known and optimized amount of BCA (30\%) in nanomaterial $(70 \%)$, then printing it on the SPE, and drying it at $80{ }^{\circ} \mathrm{C}$. BCA is known as an organic binder, and when mixed in an optimized ratio of 30:70 (BCA:nanomaterial), it results in a good thixotropic paste. The SPE is expected to play the role of conducting electrons from analyte/ZnO to the potentiostat. The cyclic voltammogram (CV) of the SPE was obtained using IVIUM's potentiostat/galvanostat at room-temperature. Different picric acid solutions of $0.0078 \mathrm{mM}$, $0.078 \mathrm{mM}, 0.78 \mathrm{mM}, 2 \mathrm{mM}, 5 \mathrm{mM}$, and $10 \mathrm{mM}$ were prepared in $0.1 \mathrm{M}$ phosphate buffer solution (PBS) $(\mathrm{pH}=7.4)$. The curves were obtained at a fix scan rate of $50 \mathrm{mV} \cdot \mathrm{s}^{-1}$, while the potential was varied from -1.0 to $1.0 \mathrm{~V}$. CV measurements were also performed at various scan rates (50 to $500 \mathrm{~m} \cdot \mathrm{Vs}^{-1}$ ) at one concentration of picric acid $(2 \mathrm{mM})$.

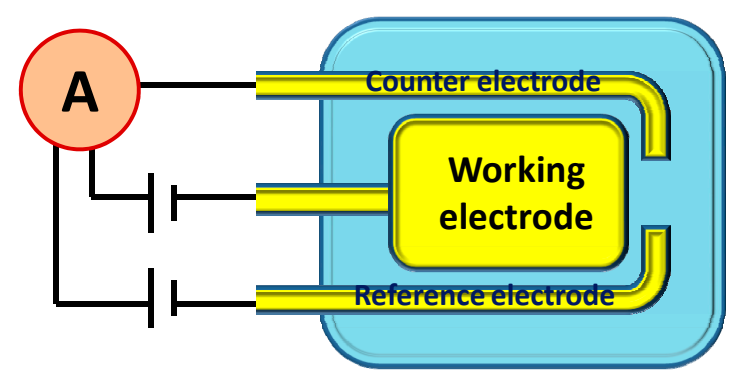

Scheme 1. Schematic representation of a screen printed electrode (SPE). 


\subsection{Fabrication of Picric Acid Sensor Based on Current-Voltage Technique Measurements}

For sensors based on the $I-V$ characteristic, a different set of electrodes were prepared. A cleaned silver electrode (AgE, surface area $=0.0214 \mathrm{~cm}^{2}$, Purity supplier) was used as one of the electrodes (working), onto which a film of nanomaterial was coated using the paste prepared for the SPE's coating. A platinum wire was used as a counter electrode. Before coating, the Ag electrodes were rubbed against an alumina gel, followed by ultrasonic cleaning and repeated washings with deionized water. The electrode was dried in an air oven for $6 \mathrm{~h}$ at 70-75 ${ }^{\circ} \mathrm{C}$. A Keithley electrometer, 6517A (USA) was used for measuring the current-voltage parameters at room temperature conditions. A platinum wire was used a counter electrode. The picric acid solutions were prepared in $0.1 \mathrm{M}$ phosphate buffer solution (PBS) having a $\mathrm{pH}=7.4$ in the scan range of $0.0-4.0 \mathrm{~V}$.

\section{Results and Discussion}

\subsection{Characterizations and Properties of $\mathrm{ZnO}$ Nanopeanuts}

The general morphologies of the synthesized material were examined by FESEM and the observed results are shown in Figure 1a,b. The observed FESEM images revealed that the prepared materials possess peanut shaped morphologies and grow in high density with almost uniform shape and size. The surface of the peanut shaped $\mathrm{ZnO}$ is highly rough, with swollen edges and a narrow central part. It is interesting to see that due to the high density growth, some nanopeanuts are linked to each other through one of their surfaces. The average diameter and length of ZnO nanopeanuts is $110 \pm 20 \mathrm{~nm}$ and $\sim 220 \pm 20 \mathrm{~nm}$, respectively. Additionally, some dumb-bell and rod-shaped morphologies are also formed due to the aggregation of two $\mathrm{ZnO}$ nanopeanuts through their ends.
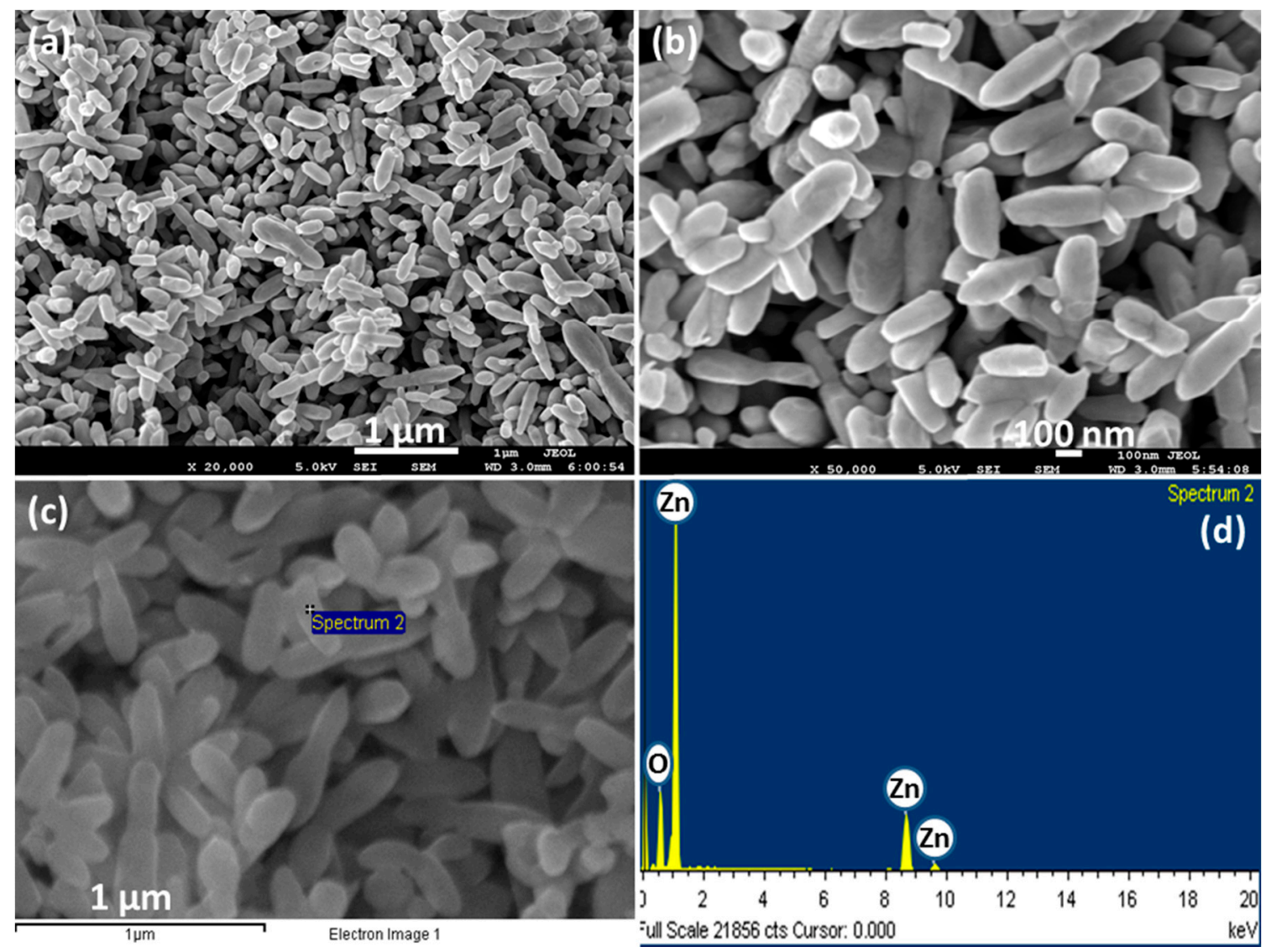

Figure 1. Typical (a,b) FESEM images; (c) EDS-SEM microscopic image and (d) EDS spectrum of the as-synthesized $\mathrm{ZnO}$ nanopeanuts. 
The rough surface of the $\mathrm{ZnO}$ peanuts provides a sufficiently large surface area for intermolecular $\pi$ stacking of the electron deficient picric acid benzene ring, which further facilitates a charge transfer from $n$-type semiconducting $\mathrm{ZnO}$ to picric acid molecules. The electron deficient nature of the picric acid benzene ring can be accounted for due to the presence of electron withdrawing nitro $\left(-\mathrm{NO}_{2}\right)$ groups. Additionally, the surface active sites of $\mathrm{ZnO}$ nanopeanuts attract the lone pairs of electrons present on the -OH group of the picric acid. The extent of chemisorptions is therefore increased, due to the high surface volume ratio of the as-synthesized $\mathrm{ZnO}$ peanuts. It has been reported that the chemisorption of the picric acid molecules amends the electronic states of the $\mathrm{ZnO}$ nanomaterials and improves the conductance [45]. These phenomena, such as charge transfer, altered electronic states, and improved conductance can be attributed to the excellent sensing performances of the $\mathrm{ZnO}$ nanomaterials.

To ascertain the elemental composition, the synthesized $\mathrm{ZnO}$ nanopeanuts were examined by energy dispersive spectroscopy (EDS) attached with FESEM (Figure 1c,d). As confirmed from the EDS spectrum, the synthesized material is made of zinc and oxygen, as no other peak related with any other element is seen in the observed EDS spectrum. The presence of only zinc and oxygen peaks in the EDS spectrum confirmed that the synthesized nanopeanuts are pure $\mathrm{ZnO}$ without any significant impurity.

It has been reported that $\mathrm{Zn}^{2+}$ ions combine with $\mathrm{NH}_{4}^{+}$and $\mathrm{HO}^{-}$ions to form $\left[\mathrm{Zn}\left(\mathrm{NH}_{3}\right)_{4}\right]^{2+}$ and $\left[\mathrm{Zn}(\mathrm{OH})_{4}\right]^{2-}$ growth units in the reaction medium [46,47]. The detailed growth mechanism for $\mathrm{ZnO}$ nanopeanuts has been elaborated elsewhere [47].

To further confirm the purity, crystal phases, and structure of the $\mathrm{ZnO}$ nanopeanuts, an $\mathrm{X}$-ray diffraction pattern was recorded between $2 \theta=10^{\circ}-80^{\circ}$. Figure 2 represents the typical XRD pattern of the as-synthesized $\mathrm{ZnO}$ nanopeanuts, which indicates a hexagonal phase of pure $\mathrm{ZnO}$ in line with the reported literature $[10,11,48,49]$. The diffraction peaks observed at $31.6^{\circ}, 34.3^{\circ}, 36.3^{\circ}, 47.4^{\circ}, 56.6^{\circ}, 62.8^{\circ}$, $66.5^{\circ}, 68.5^{\circ}, 69.7^{\circ}, 74.3^{\circ}$, and $78.2^{\circ}$ correspond to the lattice planes of $\mathrm{ZnO}(100),(002),(101),(102),(110)$, (103), (200), (112), (201), (004), and (202), respectively. No other diffraction peaks, except for a wurtzite hexagonal phase, are observed in the XRD pattern, which clearly confirmed that the synthesized nanopeanuts are only $\mathrm{ZnO}$. The results of the XRD pattern matches that of the EDS observations.

The UV-Vis. absorption spectrum for the $\mathrm{ZnO}$ nanopeanuts is shown in Figure 3a. A well-defined single exciton absorption peak at $370 \mathrm{~nm}$, corresponding to the pure wurtzite hexagonal phase, can be clearly seen, which is also in good agreement with the reported literature [48-51].

The band gap energy calculated using the well-known Planck's equation (Equation (1)) was found to be $3.35 \mathrm{eV}$ [52]. No other absorption peak, except for $370 \mathrm{~nm}$, confirms the fact that $\mathrm{ZnO}$ nanopeanuts possess excellent optical properties.

$$
\mathrm{E}_{\mathrm{g}}=\frac{\mathrm{hc}}{\lambda_{\max }}=\frac{6.625 \times 10^{-34} \mathrm{Js} .3 \times 10^{8} \mathrm{~ms}^{-1}}{370 \times 10^{-9} \mathrm{~m} .1 .6 \times 10^{-19} \mathrm{~J}_{\mathrm{eV}} \mathrm{eV}^{-1}}=3.35 \mathrm{eV},
$$

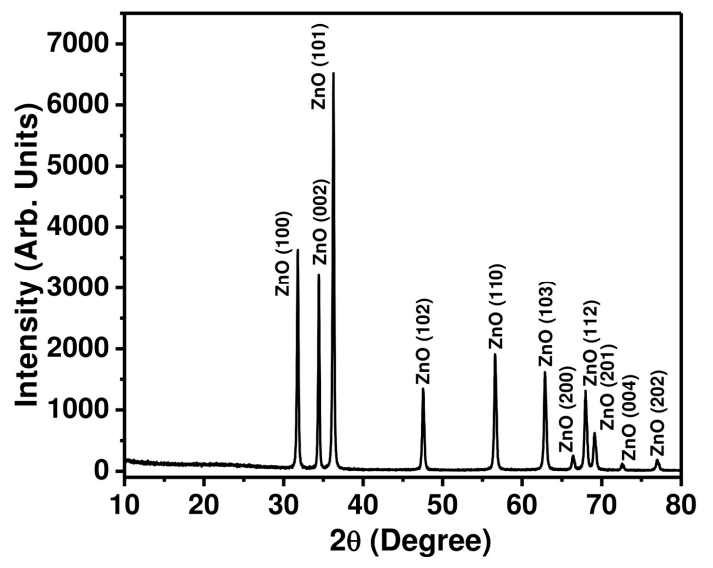

Figure 2. Typical XRD pattern for the as-synthesized $\mathrm{ZnO}$ nanopeanuts. 

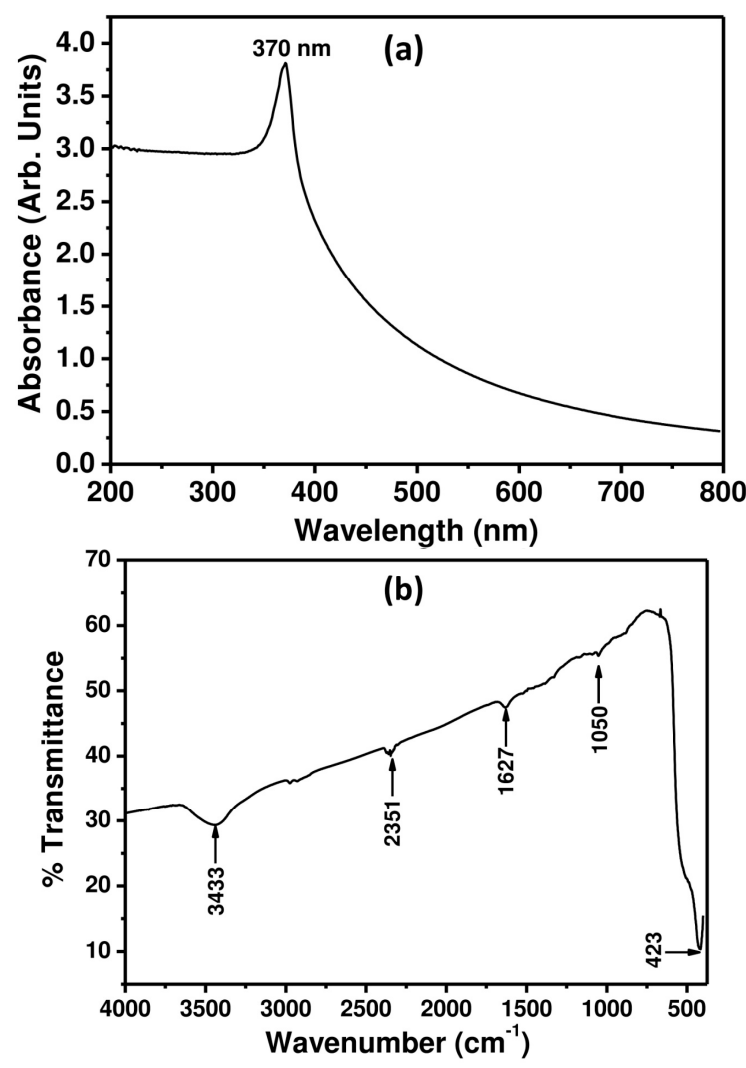

Figure 3. (a) UV-Vis and (b) FTIR spectra for the as-synthesized ZnO nanopeanuts.

Figure $3 \mathrm{~b}$ depicts a typical FTIR spectrum of the as-synthesized $\mathrm{ZnO}$ nanoflakes, which exhibits various well-defined bands appearing at $423,1050,1627,2351$, and $3433 \mathrm{~cm}^{-1}$. One sharp and well-defined peak at $423 \mathrm{~cm}^{-1}$ and another weak band at $1050 \mathrm{~cm}^{-1}$ may be assigned to the stretching and bending vibrational modes of the $\mathrm{Zn}-\mathrm{O}$ bonds, respectively [49,53]. A weak band at $1627 \mathrm{~cm}^{-1}$ and a broad band $3433 \mathrm{~cm}^{-1}$ appear due to the bending and stretching vibration modes of the $\mathrm{O}-\mathrm{H}$ groups, respectively, for the physisorbed water molecules on the surface of the $\mathrm{ZnO}$ nanopeanuts [52,54]. The low-intensity sharp band at $2351 \mathrm{~cm}^{-1}$ may be attributed to the asymmetric stretching of the $\mathrm{C}=\mathrm{O}$ bonds of $\mathrm{CO}_{2}$ molecules, adsorbed from the environment during $\mathrm{KBr}$ palletization [54].

To examine the scattering properties, the as-synthesized $\mathrm{ZnO}$ nanopeanuts were characterized by a Raman-scattering spectrum at room temperature, and the observed result is presented in Figure 4. The observed Raman-scattering spectrum exhibits various phonon peaks appearing at 330,379, 437, and $581 \mathrm{~cm}^{-1}$, which is consistent with the reported Raman-scattering spectrum of $\mathrm{ZnO}$ nanomaterials [41]. $\mathrm{ZnO}$ with a wurtzite hexagonal phase belongs to the $\mathrm{C}_{6 \mathrm{v}}^{4}(\mathrm{P} 63 \mathrm{mc})$ space group having four $\mathrm{ZnO}$ units per primitive cell. The peak corresponding to the non-polar optical phonon appeared at $437 \mathrm{~cm}^{-1}$, and is assigned to the $\mathrm{E}_{2}^{\mathrm{High}}$ mode. It is the characteristic peak for the wurtzite hexagonal phase of $\mathrm{ZnO}$. The small but sharp peak at $330 \mathrm{~cm}^{-1}$ is assigned to the $\mathrm{E}_{2 \mathrm{H}}-\mathrm{E}_{2 \mathrm{~L}}$ multi-phonon process. The other weak bands at 379 and $581 \mathrm{~cm}^{-1}$ are associated with the $\mathrm{A}_{1 \mathrm{~T}}$ and $\mathrm{E}_{1 \mathrm{~L}}$ modes, respectively. All of these peaks also match well with the reported literature values [55-57]. 


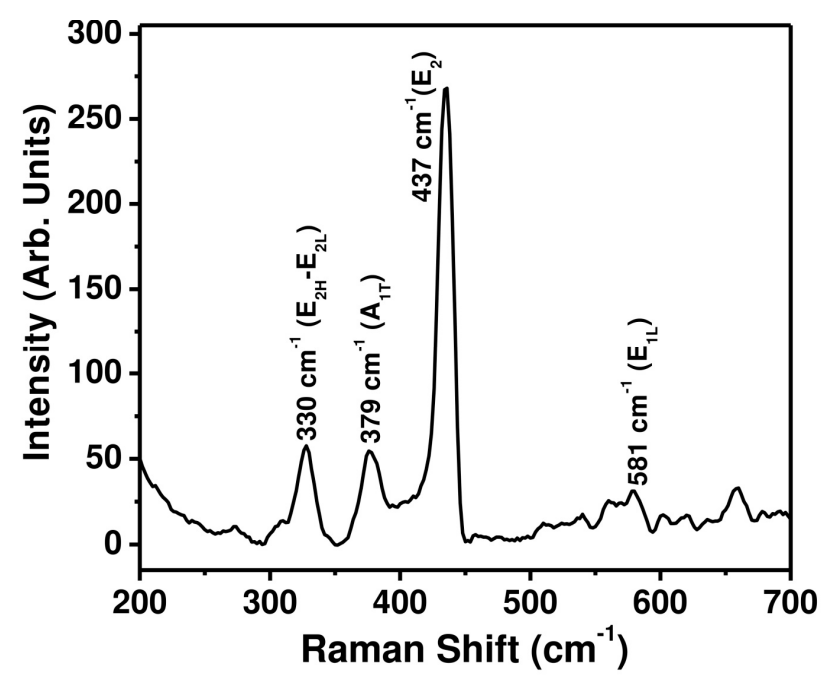

Figure 4. Typical Raman-scattering spectrum of the as-synthesized $\mathrm{ZnO}$ nanopeanuts.

\subsection{Performance of Fabricated Picric Acid Sensors Based on ZnO Nanopeanuts}

\subsubsection{Sensing Properties of Picric Acid Sensor Based on ZnO Nanopeanuts Coated SPE}

Figure 5 a shows the average CV curves of two sets of measurements of a fabricated SPE at various concentrations of picric acid $(0.0078,0.078,0.78,2,5$, and $10 \mathrm{mM})$ prepared in $0.1 \mathrm{M} \mathrm{PBS}(\mathrm{pH}=7.4)$ solution. The curves were acquired at the scan rate of $50 \mathrm{mV} / \mathrm{s}$ by varying the potential from -1.0 to $1.0 \mathrm{~V}$. The peaks observed in the CV loop are related to the oxidation and reduction of the analyte that occurred at the potential of $0.04 \mathrm{~V}$ and $-0.74 \mathrm{~V}$, respectively. A systematic increase in peak current is noticed when increasing the concentrations of picric acid, which can be clearly seen in the inset of Figure 5a. At lower concentrations of picric acid, the increase in peak currents at a lower concentration is comparatively lower than those at higher concentrations. A slight increase in peak potential is observed with increasing concentration due to changes in the dielectric constant, with analyte being used as an electrolyte. The increase in the peak current can be attributed to the increased ionic strength at the electrode-electrolyte interface, and hence the extent of the electro-catalytic reaction occurring at the surface of the modified electrode [58-61] (schematically shown later in Figure 9).

Figure $5 \mathrm{~b}$ shows the monotonic variation in the anodic peak current with concentration, which clearly shows the sensor's sensitivity to picric acid. A sudden increase in the peak current is noticed on addition of $7.8 \mu \mathrm{M}$ picric acid to PBS, indicating that the developed device is able to detect change in the analyte concentration, and although the amount of change is less still a detectable change in peak current is noticed. It has been reported in the literature that electrochemical sensors are fairly sensitive to a level of pico-mole with a measureable peak current. A further increase of picric acid amount results in a systematic increase in the peak current, indicating a linear behavior of the developed sensor. This curve can be used as a calibration curve, and the sensitivity is therefore estimated as $0.12 \mu \mathrm{A} / \mathrm{mM}$ or $9.23 \mu \mathrm{A} / \mathrm{mM} \cdot \mathrm{cm}^{-2}$ in terms of per unit area of the working electrode. The lowest experimental limit is $7.8 \mu \mathrm{M}$, which is well below the safety limit (lethal dose, an indication of lethal toxicity of the material) of picric acid $[62,63]$. 

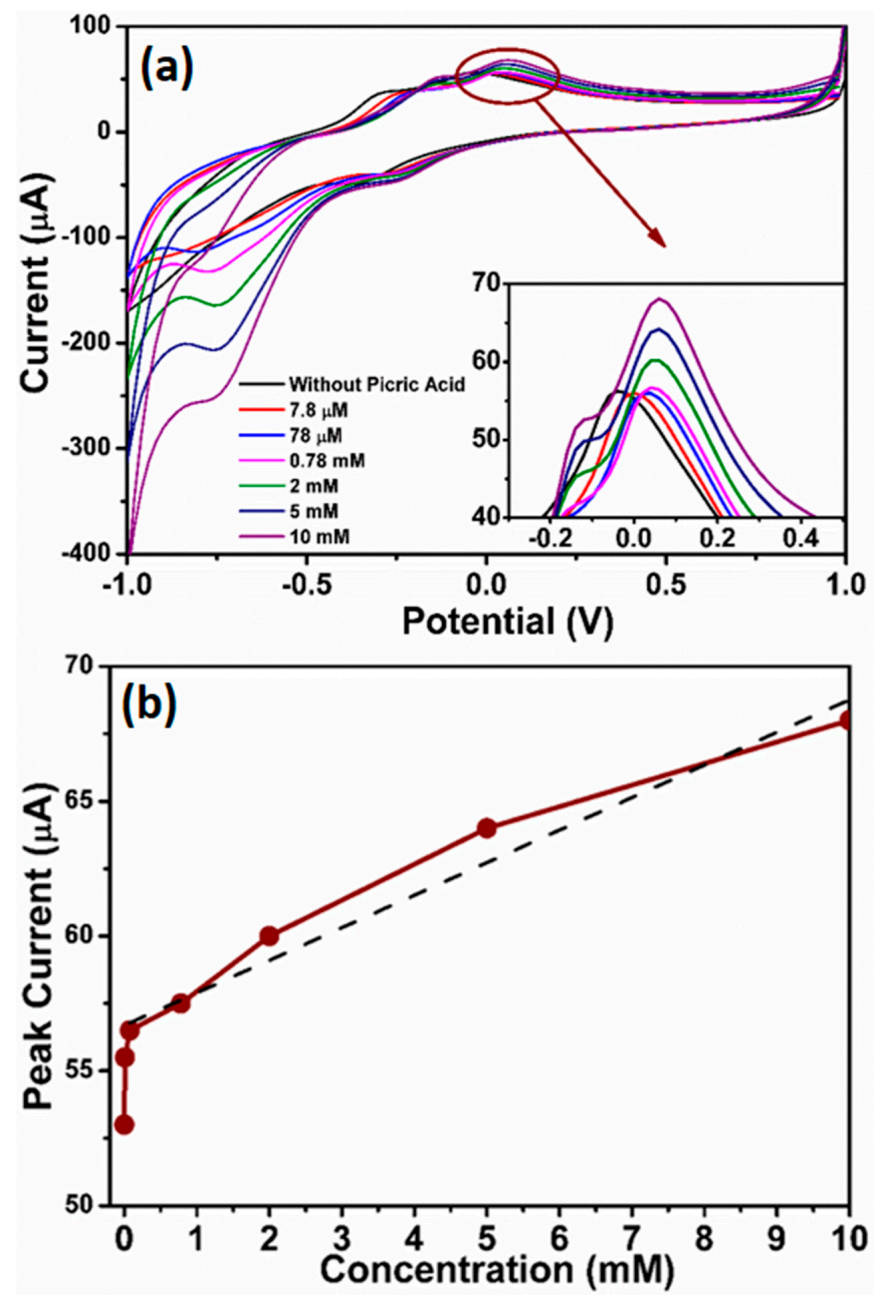

Figure 5. (a) Average cyclic voltammogram (CV) curves of the fabricated SPE at various concentrations of picric acid; and (b) Variation in the anodic peak current with concentration of picric acid.

Further, for the effect of scan rate (kinetics) on the electrochemical properties of the synthesized material, scan rate dependent CV curves were obtained. Figure 6a shows the average CV curves obtained at scan rates such as 50,100, 150, 200, 250, 300, 350, 400, and $450 \mathrm{mV} \cdot \mathrm{s}^{-1}$ at a particular concentration of $2 \mathrm{mM}$ picric acid solution. It is known that increasing the scan rate would result in increased diffusion/depletion resulting in increased peak current. Thus, from the increase in the peak currents for anodic as well as cathodic processes, it could be confirmed that the electron transfer process is a diffusion confined electrode process. 

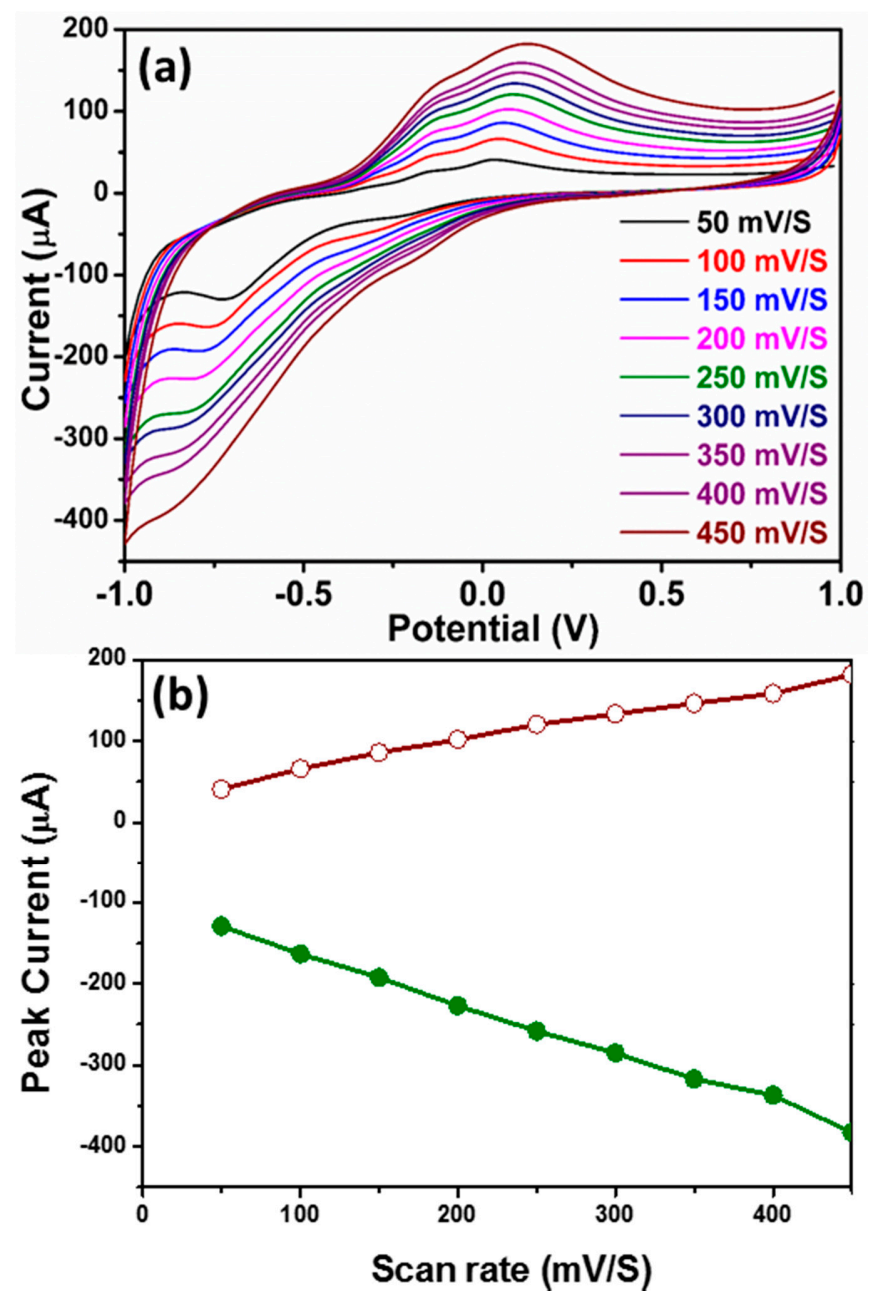

Figure 6. Typical (a) CV response curves at different scan rates (50, 100, 150, 200, 250, 300, 350, 400, and $450 \mathrm{mV} / \mathrm{S})$ for a ZnO nanopeanut-modified SPE in $0.1 \mathrm{M}$ PBS $(\mathrm{pH}=7.4)$ containing $2 \mathrm{mM}$ picric acid and (b) Variations of peak current with scan rate.

\subsubsection{Sensing Properties of Picric Acid Sensor Based on ZnO Nanopeanuts Coated on AgE}

A $\mathrm{ZnO}$ nanopeanut based sensor was fabricated to evaluate the sensing characteristics of picric acid in $0.1 \mathrm{M}$ PBS with $\mathrm{pH}=7.4$ by a simple current-voltage $(I-V)$ technique. Figure 7 represents the Current-Voltage $(I-V)$ responses for a blank $0.1 \mathrm{M}$ PBS and $0.125 \mathrm{mM}$ picric acid solution prepared in PBS having $\mathrm{pH}=7.4$, in the scan range of $0.0-4.0 \mathrm{~V}$, and using $\mathrm{ZnO}$ nanopeanut-modified AgE and $\mathrm{Pt}$ wire as a counter electrode. Prominent current variations for the picric acid solution, as compared to blank PBS, indicates that the $\mathrm{ZnO}$ nanopeanut-modified $\mathrm{AgE}$ is involved in redox changes, and hence can be used as an efficient electron mediator for electrochemical sensor applications. At $4.0 \mathrm{~V}$ potential, a current response of $16.18 \mu \mathrm{A}$ and $4.804 \mu \mathrm{A}$ were observed for the picric acid and blank solutions, respectively. 


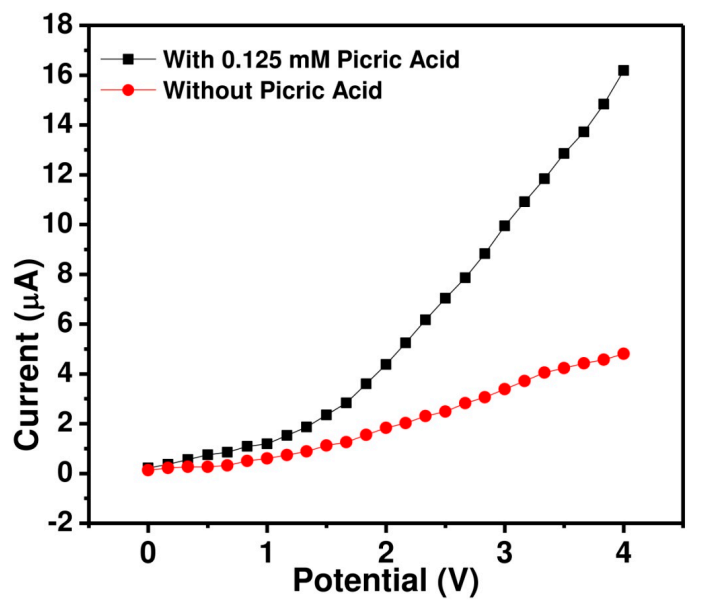

Figure 7. $\mathrm{I}-\mathrm{V}$ performances for $0.125 \mathrm{mM}$ picric acid and blank PBS using a ZnO nanopeanut-based AgE.

Figure 8a depicts the effect of picric acid concentration on $I-V$ responses. For $0.125,0.25,0.5$, 1.0, 2.1, 3.0, 4.0, and 5.0 mM solutions of picric acid solution prepared in PBS, the corresponding current responses were $16.18,29.48,38.63,47.58,68.09,78.53$, and $90.49 \mu \mathrm{A}$, respectively, measured at $4.0 \mathrm{~V}$. This positive correlation can be explained on the basis of an increase in the ionic strength of the PBS buffer solution with the concentration of the picric acid. Further, it can also be postulated that the greater the extent of chemisorptions of picric acid molecules at higher concentrations (through to a saturation point), the greater are the changes in the electronic states and conduction at the electrode-electrolyte interface of the $n$-type semiconducting $\mathrm{ZnO}$ nanopeanuts, and thus higher is the current response [60].

The sensitivity of the $\mathrm{ZnO}$ nanopeanut-modified $\mathrm{AgE}$ was calculated from the ratio of the slope of the calibration graph plotted between molar concentrations $(0.125-5.0 \mathrm{mM})$ of the picric acid solutions and the corresponding current responses measured at $4.0 \mathrm{~V}$, and the active surface area of the AgE (Equation (2)) [61] (Figure 8b).

$$
\text { Sensitivity }=\frac{\text { Slope of the calibration graph }}{\text { Active surface area of the modified } \mathrm{AgE}}
$$

A very high sensitivity of $493.64 \mu \mathrm{A} \cdot \mathrm{mM}^{-1} \cdot \mathrm{cm}^{-2}$, an experimental LOD of $0.125 \mathrm{mM}$, a linear dynamic range (LDR) of $1.0 \mathrm{mM}-5.0 \mathrm{mM}$ and a regression coefficient of $\left(R^{2}\right)=0.9980$ were observed for the fabricated $\mathrm{ZnO}$ nanopeanut-modified $\mathrm{AgE}$ sensor. Due to the lower surface area of the electrode, a comparatively higher sensitivity is observed here than with the electrochemical sensing method. The sensitivity observed herein is high as compared to the reported sensitivities of some recently reported results. Huang et al. [64] reported a sensitivity of $0.00613 \mu \mathrm{A} \cdot \mu \mathrm{M}^{-1}$ with a detection limit of $0.54 \mu \mathrm{M}$ for picric acid through a reduced graphene oxide sensor modified with 1-pyrenebutyl-amino- $\beta$-cyclodextrin. It was proposed that $\beta$-cyclodextrin with the hydrophobic internal cavity and the hydrophilic external surface has a remarkable tendency to integrate with three hydrophobic $-\mathrm{NO}_{2}$ groups of picric acid. However, there is a a low limit of detection of $0.6 \mu \mathrm{M}$ for a copper-based electrochemical sensor $[65,66]$ and $100 \mathrm{nM}$ for a boron and nitrogen co-doped carbon nanoparticles based photoluminescent sensor [67] as compared to the $\mathrm{ZnO}$ peanut-based electrochemical sensors in this study. 

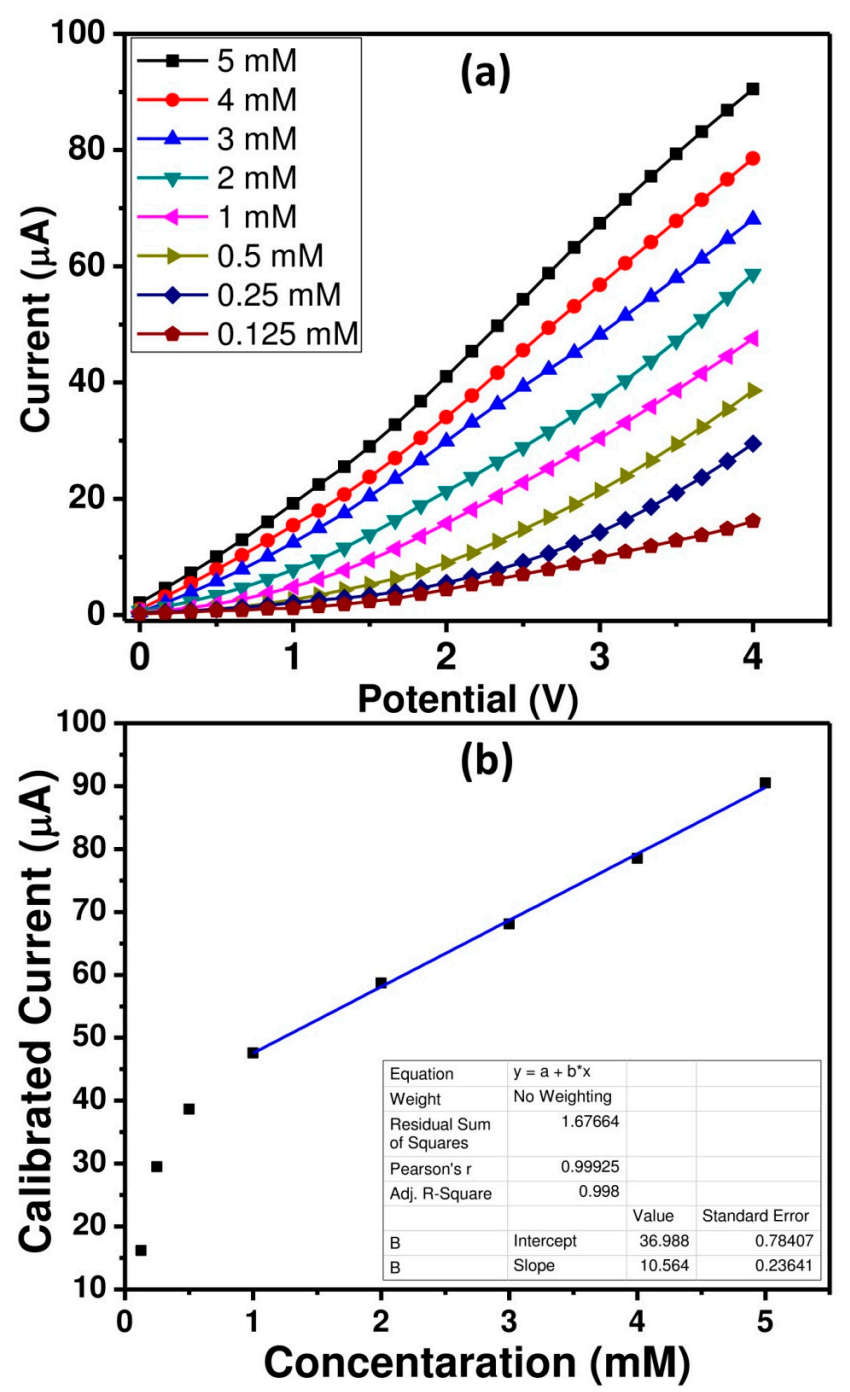

Figure 8. (a) $I-V$ responses for various concentrations of picric acid solutions (b) Calibration graph for the fabricated $\mathrm{ZnO}$ nanopeanut-modified $\mathrm{AgE}$ electrochemical sensor.

\section{Proposed Sensing Mechanism}

On the basis of Frontier molecular orbital studies, it has been shown that the adsorption of the picric acid molecules on the surface of $\mathrm{ZnO}$ lowers the energy gap between the highest occupied molecular orbital (HOMO) and the lowest unoccupied molecular orbital (LUMO), resulting in the alteration of the electronic states and hence the charge transfer and conductance of the $\mathrm{ZnO}$ nanomaterials, as stated earlier in Section 3.1 [14,45]. Picric acid molecules with electron donor hydroxy $(-\mathrm{OH})$ and electron withdrawing nitro $\left(-\mathrm{NO}_{2}\right)$ groups are adsorbed on the surface of the $\mathrm{ZnO}$ nanopeanuts through weak van der Waal interactions, where they undergo a series of redox changes [14]. Conduction band electrons of the $\mathrm{ZnO}$ nanopeanuts reduce the three $-\mathrm{NO}_{2}$ groups to intermediate hydroxylamino $(-\mathrm{HN}-\mathrm{OH})$ groups, which are subsequently oxidized to nitroso $(-\mathrm{NO})$ groups (Figure 9). The $-\mathrm{NO}$ groups undergo reversible reduction to release electrons back to the conduction band of the $\mathrm{ZnO}$ nanopeanuts, which are responsible for the increases in conductivity and current response [68]. 


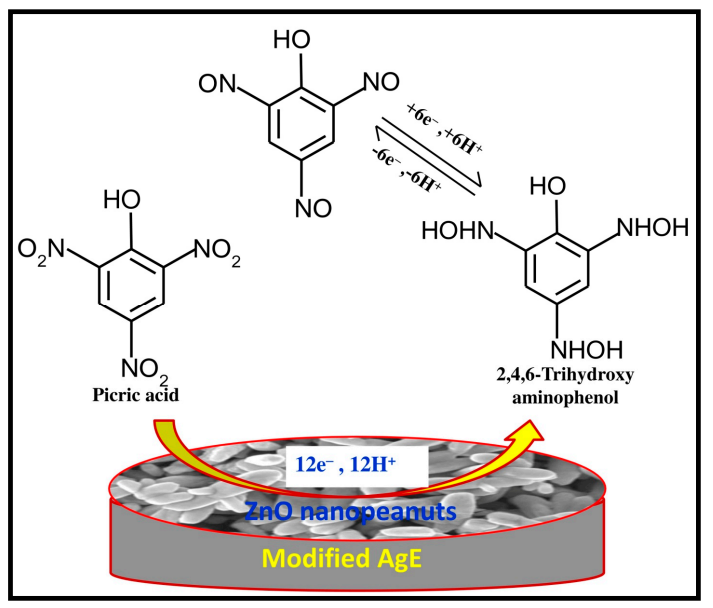

Figure 9. A sensing mechanism for picric acid sensing using modified AgE with $\mathrm{ZnO}$ nanopeanuts.

\section{Conclusions}

In summary, $\mathrm{ZnO}$ nanopeanuts were synthesized in a large quantity and characterized in detail, which revealed that the nanopeanuts possess high crystallinity and exhibit good optical and spectral properties. The synthesized nanopeanuts demonstrated high purity and were confirmed for the wurtzite hexagonal phase of pure $\mathrm{ZnO}$. Further, the synthesized nanopeanuts were explored for their picric acid sensing applications in the form of an electrochemical and electrical sensor. Reliable, reproducible, and reversible CV and IV curves were obtained, indicating the versatility of the synthesized material for an efficient, sensitive, and reliable matrix for a picric acid sensor. Hence, $\mathrm{ZnO}$ nanopeanuts can be efficiently used as excellent electron mediators for the fabrication of sensors for other nitrophenols with very high sensitive and very low LOD.

Acknowledgments: The authors extend their appreciation to the Deanship of Scientific Research at King Khalid University for funding this work through research group program under grant number R.P.G.2/5/38.

Author Contributions: All the authors have contributed equally to the manuscript.

Conflicts of Interest: The authors declare no conflicts of interest.

\section{References}

1. Chen, A.; Chatterjee, S. Nanomaterials based electrochemical sensors for biomedical applications. Chem. Soc. Rev. 2013, 42, 5425-5438. [CrossRef] [PubMed]

2. Windmiller, J.R.; Wang, J. Wearable electrochemical sensors and biosensors: A Review. Electroanalysis 2013, 25, 29-46. [CrossRef]

3. Wang, F.; Hu, S. Electrochemical sensors based on metal and semiconductor nanoparticles. Microchim. Acta 2009, 165, 1-22. [CrossRef]

4. Park, G.C.; Lee, S.M.; Jeong, S.H.; Choi, J.H.; Lee, C.M.; Seo, T.Y.; Jung, S.-B.; Lim, J.H.; Joo, J. Enhanced photocatalytic activity of $\mathrm{ZnO}$ nanorods with tubular facet synthesized by hydrothermal method. J. Nanosci. Nanotechnol. 2016, 16, 11164-11168. [CrossRef]

5. Wei, A.; Pan, L.; Huang, W. Recent progress in the ZnO nanostructure-based sensors. Mater. Sci. Eng. Solid-State Mater. Adv. Technol. 2011, 176, 1409-1421. [CrossRef]

6. Katwal, G.; Paulose, M.; Rusakova, I.A.; Martinez, J.E.; Varghese, O.K. Rapid growth of zinc oxide nanotube-nanowire hybrid architectures and their use in breast cancer related volatile organics detection. Nano Lett. 2016, 16, 3014-3021. [CrossRef] [PubMed]

7. Jeong, S.H.; Park, G.C.; Choi, J.H.; Lee, C.M.; Lee, S.M.; Seo, T.Y.; Choi, D.H.; Jung, S.B.; Lim, J.H.; Joo, J. Effect of $\mathrm{Al}$ incorporation on morphology and electrical conductivity of $\mathrm{ZnO}$ nanorods prepared using hydrothermal method. J. Nanosci. Nanotechnol. 2016, 16, 11272-11276. [CrossRef] 
8. Caglar, M.; Gorgun, K. Characterization and heterojunction application of nanorod structure ZnO films prepared by microwave assisted chemical bath deposition method without any template. J. Nanoelectron. Optoelectron. 2016, 11, 769-776. [CrossRef]

9. Kumar, R.; Al-Dossary, O.; Kumar, G.; Umar, A. Zinc oxide nanostructures for $\mathrm{NO}_{2}$ gas-sensor applications: A review. Nano-Micro Lett. 2015, 7, 97-120. [CrossRef]

10. Singh, K.; Chaudhary, G.R.; Singh, S.; Mehta, S.K. Synthesis of highly luminescent water stable ZnO quantum dots as photoluminescent sensor for picric acid. J. Lumin. 2014, 154, 148-154. [CrossRef]

11. Ameen, S.; Akhtar, M.S.; Seo, H.K.; Shin, H.S. An electrochemical sensing platform based on hollow mesoporous $\mathrm{ZnO}$ nanoglobules modified glassy carbon electrode: Selective detection of piperidine chemical. Chem. Eng. J. 2015, 270, 564-571. [CrossRef]

12. Katoch, A.; Choi, S.-W.; Sun, G.-J.; Kim, S.S. Low temperature sensing properties of Pt nanoparticle-functionalized networked ZnO nanowires. J. Nanosci. Nanotechnol. 2015, 15, 330-333. [CrossRef] [PubMed]

13. Mani, G.K.; Rayappan, J.B.B. ZnO nanoarchitectures: Ultrahigh sensitive room temperature acetaldehyde sensor. Sens. Actuators Chem. 2016, 223, 2343-2351. [CrossRef]

14. Farmanzadeh, D.; Tabari, L. DFT study of adsorption of picric acid molecule on the surface of single-walled ZnO nanotube; as potential new chemical sensor. Appl. Surf. Sci. 2015, 324, 864-870. [CrossRef]

15. Kumar, R.; Rana, D.; Umar, A.; Sharma, P.; Chauhan, S.; Chauhan, M.S. Ag-doped ZnO nanoellipsoids: Potential scaffold for photocatalytic and sensing applications. Talanta 2015, 137, 204-213. [CrossRef] [PubMed]

16. Ozden, P.B.; Caglar, Y.; Ilican, S.; Caglar, M. Effect of deposition time of electrodeposited ZnO nanorod films on crystallinity, microstructure and absorption edge. J. Nanoelectron. Optoelectron. 2016, 11, 244-249. [CrossRef]

17. Zhu, L.-P.; Jiao, Y.-H.; Bing, N.-C.; Wang, L.-L.; Ye, Y.-K.; Wang, L.-J. Influences of Ni Doping on the morphology, optical and magnetic properties of $\mathrm{ZnO}$ nanostructures synthesized by solvothermal process. J. Nanosci. Nanotechnol. 2015, 15, 3234-3238. [CrossRef] [PubMed]

18. Choi, H.J.; Lee, Y.-M.; Yu, J.-H.; Hwang, K.-H.; Boo, J.-H. Patterned well-aligned zno nanorods assisted with polystyrene monolayer by oxygen plasma treatment. Materials (Basel) 2016, 9, 656. [CrossRef]

19. Molaakbari, E.; Mostafavi, A.; Beitollahi, H.; Alizadeh, R. Synthesis of ZnO nanorods and their application in the construction of a nanostructure-based electrochemical sensor for determination of levodopa in the presence of carbidopa. Analyst 2014, 139, 4356-4364. [CrossRef] [PubMed]

20. Patra, S.; Roy, E.; Madhuri, R.; Sharma, P.K. Imprinted ZnO nanostructure-based electrochemical sensing of calcitonin: A clinical marker for medullary thyroid carcinoma. Anal. Chim. Acta 2015, 853, 271-284. [CrossRef] [PubMed]

21. Dar, G.N.; Umar, A.; Zaidi, S.A.; Baskoutas, S.; Hwang, S.W.; Abaker, M.; Al-Hajry, A.; Al-Sayari, S.A. Ultra-high sensitive ammonia chemical sensor based on ZnO nanopencils. Talanta 2012, 89, 155-161. [CrossRef] [PubMed]

22. Khan, A.; Khan, S.; Fawad, U.; Mujahid, M.; Khasim, S.; Hamdalla, T.; Kim, H.J. Three dimensional spherically evolved nanostructures of $\mathrm{ZnO}$ comprised of nanowires and nanorods for optoelectronic devices. J. Nanoelectron. Optoelectron. 2015, 10, 700-704. [CrossRef]

23. Mehta, S.K.; Singh, K.; Umar, A.; Chaudhary, G.R.; Singh, S. Ultra-high sensitive hydrazine chemical sensor based on low-temperature grown $\mathrm{ZnO}$ nanoparticles. Electrochim. Acta 2012, 69, 128-133. [CrossRef]

24. Liu, J.; Li, Y.; Jiang, J.; Huang, X. C@ZnO nanorod array-based hydrazine electrochemical sensor with improved sensitivity and stability. Dalton Trans. 2010, 39, 8693-8697. [CrossRef] [PubMed]

25. Vabbina, P.K.; Kaushik, A.; Pokhrel, N.; Bhansali, S.; Pala, N. Electrochemical cortisol immunosensors based on sonochemically synthesized zinc oxide 1D nanorods and 2D nanoflakes. Biosens. Bioelectron. 2015, 63, 124-130. [CrossRef] [PubMed]

26. Kim, J.Y.; Jo, S.Y.; Sun, G.J.; Katoch, A.; Choi, S.W.; Kim, S.S. Tailoring the surface area of ZnO nanorods for improved performance in glucose sensors. Sens. Actuator Chem. 2014, 192, 216-220. [CrossRef]

27. Jin, Z.; Park, C.-I.; Hwang, I.-H.; Han, S.-W. Local structural properties and growth mechanism of ZnO nanorods on hetero-interfaces. J. Nanosci. Nanotechnol. 2015, 15, 5306-5309. [CrossRef] [PubMed]

28. Lei, Y.; Yan, X.; Zhao, J.; Liu, X.; Song, Y.; Luo, N.; Zhang, Y. Improved glucose electrochemical biosensor by appropriate immobilization of nano-ZnO. Colloids Surf. Biointerfaces 2011, 82, 168-172. [CrossRef] [PubMed] 
29. Lee, C.T.; Chiu, Y.S.; Ho, S.C.; Lee, Y.J. Investigation of a photoelectrochemical passivated ZnO-based glucose biosensor. Sensors 2011, 11, 4648-4655. [CrossRef] [PubMed]

30. Ahmad, R.; Tripathy, N.; Hahn, Y.B. Highly stable urea sensor based on ZnO nanorods directly grown on Ag/glass electrodes. Sens. Actuator Chem. 2014, 194, 290-295. [CrossRef]

31. Ali, S.M.U.; Ibupoto, Z.H.; Salman, S.; Nur, O.; Willander, M.; Danielsson, B. Selective determination of urea using urease immobilized on $\mathrm{ZnO}$ nanowires. Sens. Actuator Chem. 2011, 160, 637-643. [CrossRef]

32. Ali, S.M.U.; Ibupoto, Z.H.; Kashif, M.; Hashim, U.; Willander, M. A potentiometric indirect uric acid sensor based on $\mathrm{ZnO}$ nanoflakes and immobilized uricase. Sensors 2012, 12, 2787-2797. [CrossRef] [PubMed]

33. Liang, Y.-C.; Chung, C.-C.; Lo, Y.-J.; Wang, C.-C. Microstructure-dependent visible-light driven photoactivity of sputtering-assisted synthesis of sulfide-based visible-light sensitizer onto $\mathrm{ZnO}$ nanorods. Materials (Basel) 2016, 9, 1014. [CrossRef]

34. Gençyilmaz, O.; Atay, F.; Akyüz, D. The effect of Co doping on ZnO films: Structural, morphological characterization and hall effect measurements. J. Nanoelectron. Optoelectron. 2015, 10, 799-805. [CrossRef]

35. Harraz, F.A.; Ismail, A.A.; Ibrahim, A.A.; Al-Sayari, S.A.; Al-Assiri, M.S. Highly sensitive ethanol chemical sensor based on nanostructured $\mathrm{SnO} 2$ doped $\mathrm{ZnO}$ modified glassy carbon electrode. Chem. Phys. Lett. 2015, 639, 238-242. [CrossRef]

36. Jeon, Y.S.; Seo, H.W.; Kim, S.H.; Kim, Y.K. Synthesis of Fe doped ZnO nanowire arrays that detect formaldehyde gas. J. Nanosci. Nanotechnol. 2016, 16, 4814-4819. [CrossRef]

37. Hu, Y.; Zhang, Z.; Zhang, H.; Luo, L.; Yao, S. Sensitive and selective imprinted electrochemical sensor for p-nitrophenol based on $\mathrm{ZnO}$ nanoparticles/carbon nanotubes doped chitosan film. Thin Solid Films 2012, 520, 5314-5321. [CrossRef]

38. Zhu, D.; He, Q.; Cao, H.; Cheng, J.; Feng, S.; Xu, Y.; Lin, T. Poly(phenylene ethynylene)-coated aligned ZnO nanorod arrays for 2,4,6-trinitrotoluene detection. Appl. Phys. Lett. 2008, 93, 11864. [CrossRef]

39. Ameen, S.; Akhtar, M.S.; Seo, H.K.; Shin, H.S. Deployment of aligned ZnO nanorod with distinctive porous morphology: Potential scaffold for the detection of p-nitrophenylamine. Appl. Catal. Gen. 2014, 470, 271-277. [CrossRef]

40. Selvam, N.C.S.; Jesudoss, S.K.; Rajan, P.I.; Kennedy, L.J.; Vijaya, J.J. Comparative investigation on the photocatalytic degradation of 2,4,6-trichlorophenol using pure and m-doped ( $\mathrm{M}=\mathrm{Ba}, \mathrm{Ce}, \mathrm{Mg}) \mathrm{ZnO}$ spherical nanoparticles. J. Nanosci. Nanotechnol. 2015, 15, 5910-5917. [CrossRef]

41. Ameen, S.; Akhtar, M.S.; Shin, H.S. Low temperature grown ZnO nanotubes as smart sensing electrode for the effective detection of ethanolamine chemical. Mater. Lett. 2013, 106, 254-258. [CrossRef]

42. U.S. Environmental Protection Agency. Nitrophenols, Ambient Water Qualify Criteria; U.S. Environmental Protection Agency: Washington, DC, USA, 1980.

43. Kaur, N.; Sharma, S.K.; Kim, D.Y.; Sharma, H.; Singh, N. Synthesis of imine-bearing ZnO nanoparticle thin films and characterization of their structural, morphological and optical properties. J. Nanosci. Nanotechnol. 2015, 15, 8114-8119. [CrossRef] [PubMed]

44. Umar, A.; Al-Hajry, A.; Ahmad, R.; Ansari, S.; Al-Assiri, M.S.; Algarni, H. Fabrication and characterization of a highly sensitive hydroquinone chemical sensor based on iron-doped ZnO nanorods. Dalton Trans. 2015, 44, 21081-21087. [CrossRef] [PubMed]

45. Ibrahim, A.; Kumar, R.; Umar, A.; Kim, S.H.; Bumajdad, A.; Ansari, Z.A.; Baskoutas, S. Cauliflower-shaped $\mathrm{ZnO}$ nanomaterials for electrochemical sensing and photocatalytic applications. Electrochim. Acta 2017, 222, 463-472. [CrossRef]

46. Ahmed, F.; Arshi, N.; Jeong, Y.S.; Anwar, M.S.; Dwivedi, S.; Alsharaeh, E.; Koo, B.H. Novel biomimatic synthesis of $\mathrm{ZnO}$ nanorods using egg white (Albumen) and their antibacterial studies. J. Nanosci. Nanotechnol. 2016, 16, 5959-5965. [CrossRef] [PubMed]

47. Prabhu, M.; Mayandi, J.; Mariammal, R.N.; Vishnukanthan, V.; Pearce, J.M.; Soundararajan, N.; Ramachandran, K. Peanut shaped ZnO microstructures: Controlled synthesis and nucleation growth toward low-cost dye sensitized solar cells. Mater. Res. Express 2015, 2, 066202. [CrossRef]

48. Wang, A.J.; Liao, Q.C.; Feng, J.J.; Zhang, P.P.; Li, A.Q.; Wang, J.J. Apple pectin-mediated green synthesis of hollow double-caged peanut-like $\mathrm{ZnO}$ hierarchical superstructures and photocatalytic applications. CrystEngComm 2012, 14, 256-263. [CrossRef]

49. Kumar, R.; Kumar, G.; Akhtar, M.S.; Umar, A. Sonophotocatalytic degradation of methyl orange using ZnO nano-aggregates. J. Alloys Compd. 2015, 629, 167-172. [CrossRef] 
50. Lee, C.-H.; Oh, S.-H. Preparation of Ga-doped $\mathrm{ZnO}$ thin films by metal-organic chemical vapor deposition with ultrasonic nebulization. J. Nanosci. Nanotechnol. 2016, 16, 11552-11557. [CrossRef]

51. Umar, A.; Kumar, R.; Kumar, G.; Algarni, H.; Kim, S.H. Effect of annealing temperature on the properties and photocatalytic efficiencies of $\mathrm{ZnO}$ nanoparticles. J. Alloys Compd. 2015, 648, 46-52. [CrossRef]

52. Umar, A.; Kumar, R.; Akhtar, M.S.; Kumar, G.; Kim, S.H. Growth and properties of well-crystalline cerium oxide (CeO2) nanoflakes for environmental and sensor applications. J. Colloid Interface Sci. 2015, 454, 61-68. [CrossRef] [PubMed]

53. Punnoose, A.; Dodge, K.; Rasmussen, J.W.; Chess, J.; Wingett, D.; Anders, C. Cytotoxicity of ZnO nanoparticles can be tailored by modifying their surface structure: A green chemistry approach for safer nanomaterials. ACS Sustain. Chem. Eng. 2014, 2, 1666-1673. [CrossRef] [PubMed]

54. Umar, A.; Lee, J.; Kumar, R.; Al-Dossary, O.; Ibrahim, A.; Baskoutas, S. Development of highly sensitive and selective ethanol sensor based on lance-shaped CuO nanostructures. Mater. Des. 2016, 105, 16-24. [CrossRef]

55. Kim, S.; Umar, A.; Kumar, R.; Algarni, H.; Kumar, G. Facile and rapid synthesis of ZnO nanoparticles for photovoltaic device application. J. Nanosci. Nanotechnol. 2015, 15, 6807-6812. [CrossRef] [PubMed]

56. Rana, U.H.S.; Kang, M.; Jeong, E.-S.; Kim, H.-S. Transition between ZnO nanorods and ZnO nanotubes with their antithetical properties. J. Nanosci. Nanotechnol. 2016, 16, 10772-10776. [CrossRef]

57. Kuriakose, S.; Satpati, B.; Mohapatra, S. Enhanced photocatalytic activity of Co doped ZnO nanodisks and nanorods prepared by a facile wet chemical method. Phys. Chem. Chem. Phys. 2014, 16, 12741-12749. [CrossRef] [PubMed]

58. Liu, S.; Li, H.; Li, S.; Li, M.; Yan, L. Synthesis, characterization and optical properties of ZnO nanostructure. J. Nanosci. Nanotechnol. 2016, 16, 8766-8771. [CrossRef]

59. Chang, W.-C.; Yu, W.-C.; Wu, C.-H.; Wang, C.-Y.; Hong, Z.-S.; Wu, R.-J. Flower-Like ZnO nanostructure for NO sensing at room temperature. J. Nanosci. Nanotechnol. 2016, 16, 9209-9214. [CrossRef]

60. Takeuchi, E.S.; Murray, R.W. Metalloporphyrin containing carbon paste electrodes. J. Electroanal. Chem. Interfacial Electrochem. 1985, 188, 49-57. [CrossRef]

61. Singh, K.; Ibrahim, A.A.; Umar, A.; Kumar, A.; Chaudhary, G.R.; Singh, S.; Mehta, S.K. Synthesis of CeO 2-ZnO nanoellipsoids as potential scaffold for the efficient detection of 4-nitrophenol. Sens. Actuator Chem. B 2014, 202, 1044-1050. [CrossRef]

62. Kim, K.Y.; Cho, C.H.; Le Shim, E. Effect of working pressure during ZnO thin-film layer deposition on transparent resistive random access memory device characteristics. J. Nanosci. Nanotechnol. 2016, 16, 10313-10318. [CrossRef]

63. Picric Acid, Human Health Effects, US Departement of Human \& Health Services. Available online: https: / / toxnet.nlm.nih.gov/cgi-bin/sis/search/a?dbs+hsdb:@term+@DOCNO+2040 (accessed on 4 January 2011).

64. Huang, J.; Wang, L.; Shi, C.; Dai, Y.; Gu, C.; Liu, J. Selective detection of picric acid using functionalized reduced graphene oxide sensor device. Sens. Actuator Chem. 2014, 196, 567-573. [CrossRef]

65. Roy, N.; Chowdhury, A.; Paul, T.; Roy, A. Morphological, optical, and raman characteristics of ZnO nanoflowers on ZnO-seeded Si substrates synthesized by chemical method. J. Nanosci. Nanotechnol. 2016, 16, 9738-9745. [CrossRef]

66. Junqueira, J.R.C.; de Araujo, W.R.; Salles, M.O.; Paixão, T.R.L.C. Flow injection analysis of picric acid explosive using a copper electrode as electrochemical detector. Talanta 2013, 104, 162-168. [CrossRef] [PubMed]

67. Sadhanala, H.K.; Nanda, K.K. Boron and nitrogen Co-doped carbon nanoparticles as photoluminescent probes for selective and sensitive detection of picric acid. J. Phys. Chem. 2015, 119, 13138-13143. [CrossRef]

68. Sharma, P.; Rana, D.S.; Umar, A.; Kumar, R.; Chauhan, M.S.; Chauhan, S. Synthesis of cadmium sulfide nanosheets for smart photocatalytic and sensing applications. Ceram. Int. 2016, 42, 6601-6609. [CrossRef]

(C) 2017 by the authors. Licensee MDPI, Basel, Switzerland. This article is an open access article distributed under the terms and conditions of the Creative Commons Attribution (CC BY) license (http://creativecommons.org/licenses/by/4.0/). 